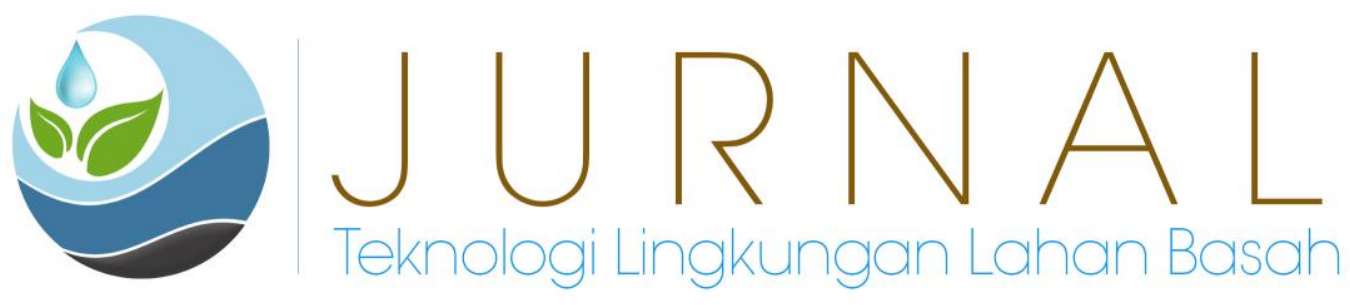

\title{
Analisis Penentuan Skala Prioritas Genangan atau Banjir di Kecamatan Bogor Selatan
}

\author{
Anita Rufina ${ }^{1}$, Eka Wardhani S.T., M.T ${ }^{1}$, Lina Apriyanti Sulistyowati S.T., M.T ${ }^{1}$ \\ 1.Jurusan Teknik Lingkungan, Insitut Teknologi Nasional Bandung \\ E-mail : rufinaanita@gmail.com
}

\begin{abstract}
Drainage system is a water structure that has a function to reduce excess water from an area or land (Suripin, 2004). Based on the 2018 Bogor City Drainage Masterplan, there are drainage channel problems in 18 flood innudation points in South Bogor District. Out of 18 innudation points, 9 points have been choosen to be prioritized according to a priority scale after comparing parameters stated in Minister of Public Works and Public Housing Regulation No.12 of 2014 concerning the Implementations of Urban Drainage System. The 9 innudation points are located in 4 villages, and villages with the highest flood innudation points are Lawanggintung, Cikaret, Kertamaya and Batutulis. Flooding in South Bogor District is caused by problems in the drainage channel system. Problems that arise includes the conversion of irrigation and waste in drainage channels, overloaded drainage channels, broken water embankment, lack of drainage channels, reduction of channel capacity by permanently narrowing or closing channels, lack of channel capacity, as well channel siltation due to the waste.
\end{abstract}

Keywords: drainage, water puddles, flooding

\begin{abstract}
Abstrak
Sistem drainase merupakan bangunan air yang memiliki fungsi untuk mengurangi kelebihan air dari suatu kawasan atau lahan. (Suripin, 2004). Berdasarkan masterplan drainase Kota Bogor tahun 2018, Kecamatan Bogor Selatan memiliki permasalahan saluran drainase meliputi 18 titik genangan banjir. Pada 18 titik genangan banjir, terdapat 9 titik genangan banjir yang menjadi prioritas berdasarkan metode skala prioritas, yakni dengan memberikan skoring pada kondisi genangan terhadap parameter-parameter yang terdapat pada Peraturan Menteri Pekerjaan Umum dan Perumahan Rakyat No.12 Tahun 2014 tentang Penyelenggaraan Sistem Drainase Perkotaan. Daerah yang meliputi 9 titik genangan banjir tersebar di 4 kelurahan. Kelurahan dengan titik genangan banjir paling tinggi adalah Kelurahan Lawanggintung, Cikaret, Kertamaya, dan Batutulis. Permasalahan yang menyebabkan terjadinya genangan banjir di wilayah Kecamatan Bogor Selatan adalah pada sistem saluran drainase. Permasalahan yang timbul meliputi alih fungsi saluran irigasi dan sampah, kapasitas saluran drainase terlampaui, rusaknya tanggul penampung air, belum adanya saluran drainase, pengurangan kapasitas saluran seperti tertutupnya saluran secara permanen dan penyempitan, kapasitas saluran drainase yang minim, serta terjadinya pendangkalan saluran oleh sampah.
\end{abstract}

Kata Kunci: drainase, genangan air, banjir 


\section{PENDAHULUAN}

Terjadinya genangan banjir di wilayah Kecamatan Bogor Selatan dikarenakan ada permasalahan pada sistem saluran drainase. Permasalahan yang timbul meliputi alih fungsi saluran irigasi dan sampah, kapasitas saluran drainase yang sudah terlampaui, tanggul penampung air rusak, belum adanya saluran drainase pada suatu kawasan, adanya pengurangan kapasitas saluran seperti tertutupnya saluran secara permanen dan penyempitan, kapasitas saluran drainase yang minim, serta terjadinya pendangkalan saluran oleh sampah.

Perbaikan perlu dilakukan dengan menganalisis titik genangan banjir yang menjadi prioritas pada saluran yang memerlukan perbaikan. Penentuan skala prioritas ditentukan berdasarkan metode skala prioritas dengan membandingkan kondisi sistem drainase yang meliputi parameter genangan atau banjir yang mencakup kedalaman genangan, luas genangan, lama genangan, dan frekuensi genangan yang terdapat pada Peraturan Menteri Pekerjaan Umum dan Perumahan Rakyat No.12 Tahun 2014 tentang Penyelenggaraan Sistem Drainase Perkotaan.

Penilaian skala prioritas juga dilakukan dengan melihat dari aspek kriteria kerugian ekonomi, kriteria gangguan sosial dan fasilitas pemerintah, kriteria kerugian dan gangguan transportasi, kriteria kerugian pada daerah perumahan, serta kriteria kerugian hak milik dan pribadi. Tujuan penelitian ini untuk mengetahui skala prioritas penanganan genangan atau banjir di sistem drainase Kecamatan Bogor Selatan. Manfaat dari penelitian untuk memberikan informasi mengenai tingkat prioritas terhadap genangan atau banjir dalam meningkatkan perbaikan sistem drainase di Kecamatan Bogor Selatan.

\section{METODE PENELITIAN}

Langkah awal dari pengerjaan metodologi studi yaitu dengan mengetahui wilayah yang memiliki permasalahan dari genangan atau banjir bedasarkan parameter kriteria genangan atau banjir melalui data sekunder dari BAPPEDA Kota Bogor. Penelitian dilakukan di Kecamatan Bogor Selatan, Kota Bogor, Jawa Barat.

Parameter-parameter yang mencakup skala prioritas genangan banjir adalah parameter genangan atau banjir yang mencakup akan kedalaman genangan, luas genangan, lama genangan, dan frekuensi genangan. Selain paramater tersebut, juga terdapat parameter aspek kriteria kerugian ekonomi, kriteria gangguan sosial dan fasilitas pemerintah, kriteria kerugian dan gangguan transportasi, kriteria kerugian pada daerah perumahan, serta kriteria kerugian hak milik dan pribadi. Diagram alir penelitian dapat dilihat pada Gambar 1. 


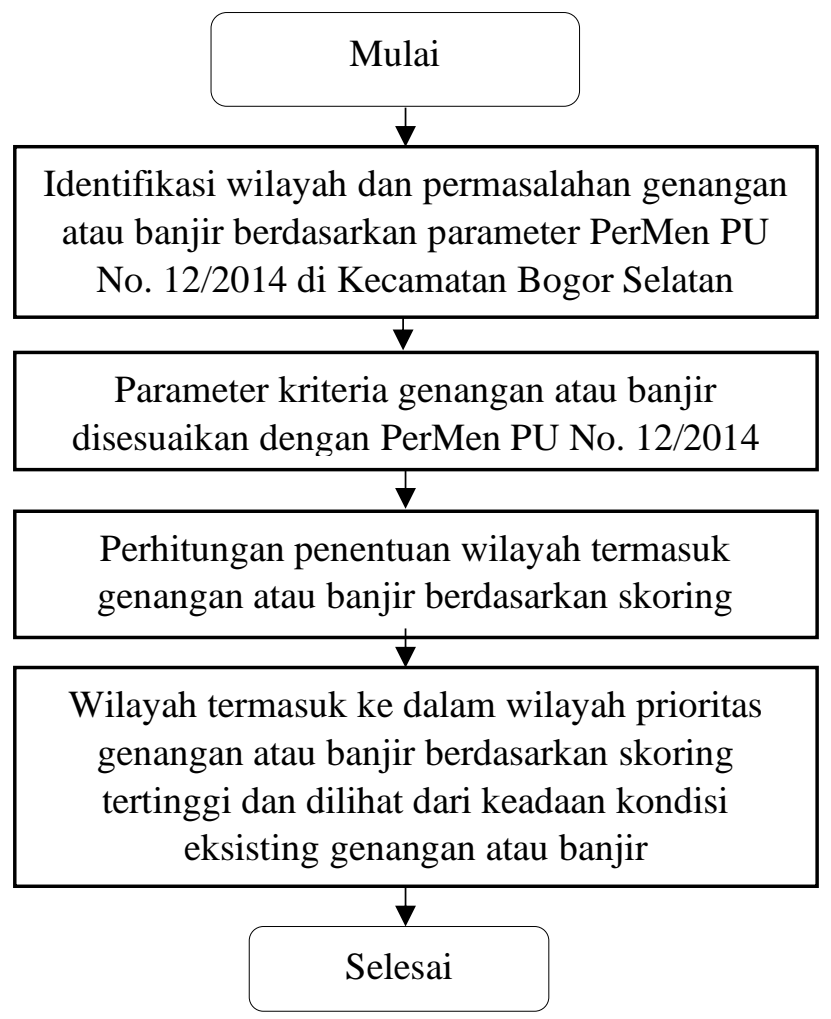

Gambar 1. Diagram Alir Metode Penelitian

Berikut adalah paramater-parameter kriteria genangan atau banjir berdasarkan Peraturan Menteri Pekerjaan Umum dan Perumahan Rakyat No.12 Tahun 2014 pada Tabel 1, Tabel 2, Tabel 3, Tabel 4, Tabel 5, dan Tabel 6.

Tabel 1. Nilai Parameter Genangan atau Banjir

\begin{tabular}{|c|c|c|c|}
\hline No. & Parameter Genangan/Banjir & Nilai & Persentase Nilai \\
\hline \multirow[t]{6}{*}{1.} & Kedalaman Genangan & \multirow{6}{*}{35} & \\
\hline & $>0,050 \mathrm{~m}$ & & 100 \\
\hline & $0,30-0,50 \mathrm{~m}$ & & 75 \\
\hline & $0,20-0,30 \mathrm{~m}$ & & 50 \\
\hline & $0,10-0,20 \mathrm{~m}$ & & 25 \\
\hline & $<0,10 \mathrm{~m}$ & & 0 \\
\hline \multirow[t]{6}{*}{2.} & Luas Genangan & \multirow{6}{*}{25} & \\
\hline & $>8,0 \mathrm{Ha}$ & & 100 \\
\hline & $4,0-8,0 \mathrm{Ha}$ & & 75 \\
\hline & $2,0-4,0 \mathrm{Ha}$ & & 50 \\
\hline & $1,0-2,0 \mathrm{Ha}$ & & 25 \\
\hline & $<1,0 \mathrm{Ha}$ & & 0 \\
\hline \multirow[t]{6}{*}{3.} & Lama Genangan & \multirow{6}{*}{20} & \\
\hline & $>8,0$ jam & & 100 \\
\hline & $4,0-8,0$ jam & & 75 \\
\hline & 2,0-4,0 jam & & 50 \\
\hline & $1,0-2,0$ jam & & 25 \\
\hline & $<1,0$ jam & & 0 \\
\hline 4. & Frekuensi Genangan & 20 & \\
\hline
\end{tabular}




\begin{tabular}{|l|l|c|}
\hline Sangat sering (10 kali/tahun) & \multirow{4}{*}{} & 100 \\
& Sering (6 kali/tahun) & 75 \\
& Kurang sering (3 kali/tahun) & 50 \\
& Jarang (1 kali/tahun) & 25 \\
& Tidak pernah kebanjiran & 0 \\
\cline { 3 - 3 }
\end{tabular}

(Sumber: Permen PUPR No.12, 2014)

Tabel 2. Kriteria Kerugian Ekonomi

\begin{tabular}{|c|l|c|c|}
\hline No. & \multicolumn{1}{|c|}{ Parameter } & Pengaruh/Kerugian & Nilai \\
\hline 1. & $\begin{array}{l}\text { Genangan air/banjir terjadi pada daerah industri, } \\
\text { daerah komersial dan daerah perkantoran padat }\end{array}$ & Tinggi & 100 \\
\hline 2. & $\begin{array}{l}\text { Genangan air/banjir terjadi pada daerah industri dan } \\
\text { daerah komersial yang kurang padat }\end{array}$ & Kedang & 65 \\
\hline 3. & $\begin{array}{l}\text { Genangan air/banjir mempengaruhi atau terjadi di } \\
\text { daerah perumahan dan/atau daerah pertanian (dalam } \\
\text { daerah perkotaan yang terbatas) }\end{array}$ & Sangat Kecil & 0 \\
\hline 4. & $\begin{array}{l}\text { Terjadi genangan pada daerah yang jarang } \\
\text { penduduknya dan daerah yang tidak produktif }\end{array}$ & \multicolumn{1}{|c|}{ Kuntal Permen PUPR No.12, } \\
\hline
\end{tabular}

(Sumber: Permen PUPR No.12, 2014)

Tabel 3. Kriteria Gangguan Sosial dan Fasilitas Pemerintah

\begin{tabular}{|c|l|c|c|}
\hline No. & \multicolumn{1}{|c|}{ Parameter } & Pengaruh/Kerugian & Nilai \\
\hline 1. & $\begin{array}{l}\text { Genangan air/banjir terjadi pada daerah yang banyak } \\
\text { pelayanan fasilitas sosial dan fasilitas pemerintah }\end{array}$ & Tinggi & 100 \\
\hline 2. & $\begin{array}{l}\text { Genangan air/banjir terjadi di daerah yang sedikit } \\
\text { pelayanan fasilitas sosial dan fasilitas pemerintah }\end{array}$ & Kedang & 65 \\
\hline 3. & $\begin{array}{l}\text { Genangan air/banjir mempengaruhi atau terjadi di } \\
\text { daerah yang pelayanan sosial dan fasilitas } \\
\text { pemerintah terbatas }\end{array}$ & Sangat kecil & 0 \\
\hline 4. & Jika tidak ada fasilitas sosial dan fasilitas pemerintah & \multicolumn{1}{|c|}{ Kecil } \\
\hline
\end{tabular}
(Sumber: Permen PUPR No.12, 2014)

Tabel 4. Kriteria Kerugian dan Gangguan Transportasi

\begin{tabular}{|c|l|c|c|}
\hline No. & \multicolumn{1}{|c|}{ Parameter } & Pengaruh/Kerugian & Nilai \\
\hline 1. & $\begin{array}{l}\text { Genangan air/banjir terjadi pada daerah yang } \\
\text { jaringan transportasinya padat }\end{array}$ & Tinggi \\
\hline 2. & $\begin{array}{l}\text { Genangan air/banjir terjadi di daerah yang jaringan } \\
\text { transportasinya kurang padat }\end{array}$ & Kecil & 30 \\
\hline 3. & $\begin{array}{l}\text { Genangan air/banjir mempengaruhi atau terjadi di } \\
\text { daerah yang jaringan transportasinya terbatas }\end{array}$ & Sangat kecil & 0 \\
\hline 4. & Jika tidak ada jaringan jalan & & \\
\hline
\end{tabular}

(Sumber: Permen PUPR No.12, 2014) 
Tabel 5. Kriteria Kerugian Pada Daerah Perumahan

\begin{tabular}{|c|l|c|c|}
\hline No. & \multicolumn{1}{|c|}{ Parameter } & Pengaruh/Kerugian & Nilai \\
\hline 1. & $\begin{array}{l}\text { Genangan air/banjir terjadi pada perumahan padat } \\
\text { sekali }\end{array}$ & Sedang & 65 \\
\hline 2. & $\begin{array}{l}\text { Genangan air/banjir terjadi pada perumahan yang } \\
\text { kurang padat }\end{array}$ & Kecil & 30 \\
\hline 3. & $\begin{array}{l}\text { Genangan air/banjir mempengaruhi atau terjadi di } \\
\text { yang hanya pada beberapa bangunan perumahan }\end{array}$ & Sangat kecil & 0 \\
\hline 4. & $\begin{array}{l}\text { Jika tidak ada perumahan pada daerah genangan } \\
\text { air/banjir }\end{array}$ &
\end{tabular}

(Sumber: Permen PUPR No.12, 2014)

Tabel 6. Kriteria Kerugian Hak Milik Pribadi

\begin{tabular}{|c|l|c|c|}
\hline No. & \multicolumn{1}{|c|}{ Parameter } & Pengaruh/Kerugian & Nilai \\
\hline 1. & Kerugian lebih dari $80 \%$ nilai milik pribadi & Tinggi & 100 \\
\hline 2. & Kerugian $80 \%$ dari nilai milik pribadi & Sedang & 65 \\
\hline 3. & Kerugian kurang dari $40 \%$ nilai milik pribadi & Kecil & 30 \\
\hline 4. & Tidak ada kerugian milik pribadi & Sangat kecil & 0 \\
\hline
\end{tabular}

(Sumber: Permen PUPR No.12, 2014)

Berdasarkan penentuan skala prioritas menggunakan parameter-parameter tersebut, data pada Tabel 1 menunjukkan pengumpulan dari data sekunder yang mengacu kepada parameter genangan atau banjir yang mencakup akan kedalaman genangan, luas genangan, lama genangan, dan frekuensi genangan dari BAPPEDA Kota Bogor serta melakukan observasi terhadap kondisi eksisting saluran drainase di wilayah studi. Data Tabel 2 berisi informasi mengenai kriteria kerugian ekonomi yang didapatkan dari data sekunder mengenai pengaruh genangan atau banjir yang mempengaruhi dari sektor kawasan industri dan kawasan komersial. Data Tabel 3 berisi informasi mengenai kriteria gangguan sosial dan fasilitas pemerintah yang didapatkan berdasarkan data sekunder mengenai pengaruh genangan atau banjir terhadap fasilitas yang terdapat di lokasi kajian studi. Data Tabel 4 berisi informasi mengenai kriteria kerugian dan gangguan transportasi yang didapatkan berdasarkan data sekunder gangguan lalu lintas atau transportasi sehingga mengakibatkan kecametan yang diakibatkan oleh genangan atau banjir. Data Tabel 5 berisi informasi mengenai kriteria kerugian pada daerah perumahan yang didapatkan berdasarkan data sekunder mengenai pengaruh genangan atau banjir terhadap kawasan perumahan di lokasi kajian studi. Data Tabel 6 berisi informasi mengenai kriteria kerugian hak milik pribadi pada harta benda pemilik di lokasi kajian studi yang mengalami kerugian akibat kerusakan karena adanya pengaruh genangan atau banjir. Perhitungan skoring akhir dari parameter genangan atau banjir dengan perhitungan Nilai $=$ Nilai $x$ persentase parameter $(\%)$

\section{HASIL DAN PEMBAHASAN}

Kecamatan Bogor Selatan merupakan salah satu dari dua Kecamatan terbesar di Kota Bogor selain Kecamatan Bogor Selatan yang memiliki 16 kelurahan sebagai wilayah pemekaran dari Kabupaten Bogor. Kecamatan Bogor Selatan terdiri dari 16 kelurahan. Kecamatan Bogor Selatan memiliki luas $3081 \mathrm{Ha}$ atau $30,81 \mathrm{~km}^{2}$, dengan kepadatan penduduk 111 jiwa/Ha. Kecamatan ini terletak pada $6^{\circ} 36$ '41,3" - 6 ${ }^{\circ} 40$ '2,2" LS dan $106^{\circ} 46^{\prime} 45,7^{\prime}$ ' - 106 50 '30,7' BT. Topografi rata-rata dengan kemiringan lahan landai > 
15 derajat dan kemiringan lahan sedang 15-25 derajat dengan tanah tahan terhadap erosi, kondisi agak peka.Kota Bogor memiliki rata-rata curah hujan 3.500-4.000 mm dengan kelembapan udara 70\%. Kecamatan Bogor Selatan dilewati oleh DAS Ciliwung dan DAS Cisadane.

Berdasarkan masterplan drainase Kota Bogor tahun 2018, Kecamatan Bogor Selatan memiliki permasalahan drainase meliputi 18 titik genangan banjir dengan 9 titik menjadi prioritas meliputi 4 kelurahan, yakni Lawanggintung, Kertamaya, Cikaret dan Batutulis. Berikut adalah peta titik genangan atau banjir pada Gambar 2.

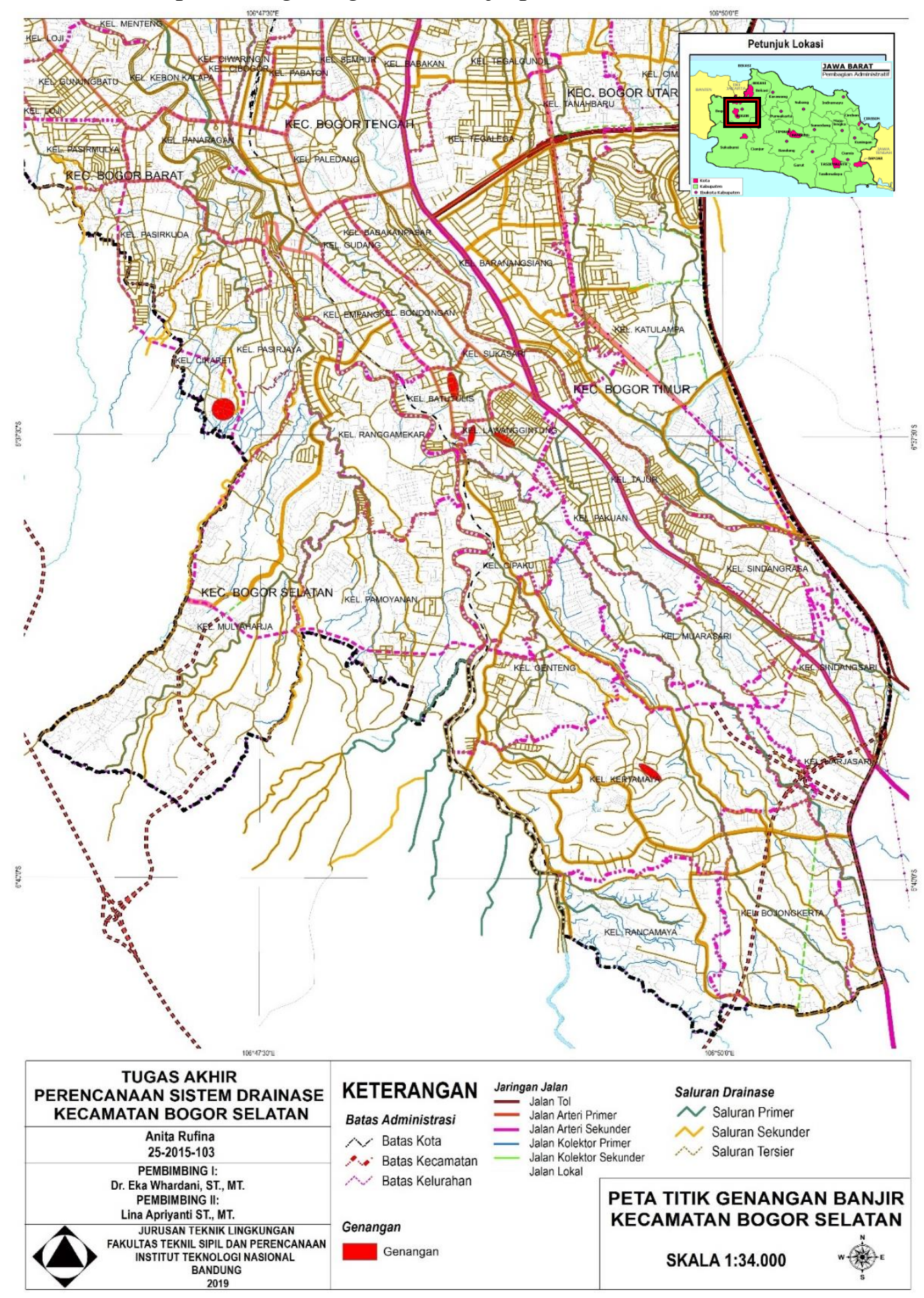

Gambar 2 Peta Titik Genangan atau Banjir (Sumber : BAPPEDA, 2018) 
Berdasarkan hasil analisis didapatkan hasil skoring dari penilaian skala prioritas genangan atau banjir yang dirangkum pada Tabel 7.

Tabel 7. Hasil Perhitungan Skala Prioritas

\begin{tabular}{|c|c|c|c|c|c|}
\hline No. & Kelurahan & $\begin{array}{l}\text { Lokasi } \\
\text { Genangan }\end{array}$ & Penyebab Genangan & Nilai Total & $\begin{array}{l}\text { Skala } \\
\text { Prioritas }\end{array}$ \\
\hline 1. & Lawanggintung & RW 1 & $\begin{array}{l}\text { Kapasitas saluran } \\
\text { terlampaui, lama } \\
\text { genangan } 4 \text { jam }\end{array}$ & 88,25 & 2 \\
\hline 2. & Lawanggintung & RW 8 & Tanggul rusak & 260 & 2 \\
\hline 3. & Kertamaya & RW 5 & $\begin{array}{l}\text { Tidak ada saluran } \\
\text { drainase }\end{array}$ & 148,75 & 2 \\
\hline 4. & Cikaret & RW 7 & $\begin{array}{l}\text { Alih fungsi saluran } \\
\text { irigasi dan sampah }\end{array}$ & 225 & 1 \\
\hline 5. & Cikaret & RW 7 & $\begin{array}{l}\text { Alih fungsi saluran } \\
\text { irigasi dan sampah }\end{array}$ & 287,5 & 1 \\
\hline 6. & Cikaret & RW 4 & $\begin{array}{l}\text { Alih fungsi saluran } \\
\text { irigasi dan sampah }\end{array}$ & 282,25 & 1 \\
\hline 7. & Cikaret & RW 5 & $\begin{array}{l}\text { Alih fungsi saluran } \\
\text { irigasi dan sampah }\end{array}$ & 291,15 & 1 \\
\hline 8. & Cikaret & RW 5 & $\begin{array}{l}\text { Alih fungsi saluran } \\
\text { irigasi dan sampah }\end{array}$ & 286,25 & 1 \\
\hline 9. & Batutulis & RW 5 & $\begin{array}{l}\text { Kapasitas saluran } \\
\text { terlampaui }\end{array}$ & 265 & 1 \\
\hline
\end{tabular}

(Sumber: Hasil Analisis, 2019)

Penentuan skala prioritas didasarkan pada perhitungan nilai dari parameter-parameter yang terdapat pada Peraturan Menteri Pekerjaan Umum dan Perumahan Rakyat No.12 Tahun 2014. Berdasarkan hasil perhitungan dan pengolahan data meliputi 6 parameter terkait, didapatkan hasil 9 titik genangan atau banjir di Kecamatan Bogor Selatan. Prioritas tertinggi ditentukan berdasarkan nilai terbesar yang didapat. Berdasarkan perhitungan, skala prioritas 1 meliputi Kelurahan Cikaret meliputi RW 7 (Jalan Raden Kosasih dan Gang Basir), RW 4 (Gang Basir), RW 5 (Jalan Kapten Yusuf), dan RW 5 (Gang Emad). Selain itu juga terdapat di Kelurahan Lawanggintung (RW 8, Gang Dalem) dan Kelurahan Batutulis (RW 5, di saluran Irigasi Surya Kencana).

Berdasarkan hasil survey dan dari masterplan drainase Kota Bogor tahun 2018, didapat hasil kondisi eksisiting berdasarkan masing-masing parameter dapat dilihat pada Tabel 8 dan Tabel 9. 
Tabel 8. Hasil Survey Kondisi Eksisting Berdasarkan Parameter Genangan atau Banjir

\begin{tabular}{|l|l|l|l|l|}
\hline Nama Wilayah & $\begin{array}{l}\text { Tinggi } \\
\text { Genangan (m) }\end{array}$ & $\begin{array}{l}\text { Luas } \\
\text { Genangan (Ha) }\end{array}$ & $\begin{array}{l}\text { Lamanya } \\
\text { Genangan } \\
\text { (jam) }\end{array}$ & $\begin{array}{l}\text { Frekuensi } \\
\text { Genangan }\end{array}$ \\
\hline $\begin{array}{l}\text { Kelurahan } \\
\text { Cikaret RW 05 } \\
\text { (Jalan Kapten } \\
\text { Yusuf) }\end{array}$ & $>0,50$ & $1-2$ & $2-4$ & $\begin{array}{l}\text { Kurang sering } \\
=3 \text { kali/tahun }\end{array}$ \\
\hline
\end{tabular}

(Sumber: Hasil Survey, 2018)

Tabel 9. Hasil Survey Kondisi Eksisting Berdasarkan Parameter Kerugian Ekonomi, Gangguan Sosial dan Fasilitas Pemerintah, Gangguan Transportasi, Perumahan, dan Pribadi

\begin{tabular}{|l|l|l|l|l|l|}
\hline $\begin{array}{l}\text { Nama } \\
\text { Wilayah }\end{array}$ & Ekonomi & $\begin{array}{l}\text { Gangguan } \\
\text { Sosial dan } \\
\text { Fasilitas } \\
\text { Pemerintah }\end{array}$ & $\begin{array}{l}\text { Gangguan } \\
\text { Kerugian } \\
\text { Transportasi }\end{array}$ & Perumahan & Pribadi \\
\hline $\begin{array}{l}\text { Kelurahan } \\
\text { Cikaret RW } \\
\text { 05 (Jalan } \\
\text { Kapten } \\
\text { Yusuf) }\end{array}$ & Kecil & Sangat kecil & Tinggi & Sedang & Kecil \\
\hline
\end{tabular}

(Sumber: Hasil Survey, 2018)

Berikut merupakan contoh perhitungan dari perhitungan skoring untuk wilayah Kelurahan Cikaret RW 05 Jalan Kapten Yusuf :

Perhitungan skoring parameter genangan atau banjir

Nilai $=$ Nilai $x$ persentase parameter $(\%)$

$$
\begin{aligned}
& =\left[\left(\frac{100}{100} \times 35\right)+\left(\frac{25}{100} \times 25\right)+\left(\frac{50}{100} \times 50\right)+\left(\frac{50}{100} \times 50\right)\right] \\
& =61,25
\end{aligned}
$$

Perhitungan skoring parameter kerugian ekonomi, gangguan sosial dan fasilitas sosial, gangguan kerugian transportasi, perumahan dan pribadi

Nilai $=30+0+100+65+30$

$$
=225
$$

Nilai total $=61,25+225$

$$
=286,25
$$

Kelurahan Cikaret memiliki masalah yang mengakibatkan genangan atau banjir dengan tipikal sama yaitu karena adanya alih fungsi saluran irigasi menjadi tempat pembuangan sampah sehingga terjadi pendangkalan saluran, menyebabkan terjadinya penyempitan saluran. Kelurahan Batutulis memiliki masalah dengan saluran yang saat musim hujan menampung air hujan di dalam saluran kapasitas saluran tidak cukup untuk menampung air, sehingga terjadi genangan atau banjir hal ini disebabkan oleh karena adanya pendangkalan karena sampah yang dibuang di dalam saluran. Kelurahan Lawanggintung 
memiliki masalah dengan tanggul rusak. Tanggul terletak dekat saluran primer untuk menahan air yang terakumulasi dalam saluran supaya tidak masuk ke ruas jalan. Akibat dari tanggul rusak mengakibatkan banjir atau genangan dijalan. Sehingga untuk nilai skoring tinggi $>200$ termasuk kedalam skala prioritas 1 . Berikut adalah gambar dari kondisi eksisting saluran drainase dapat dilihat pada Gambar 3.

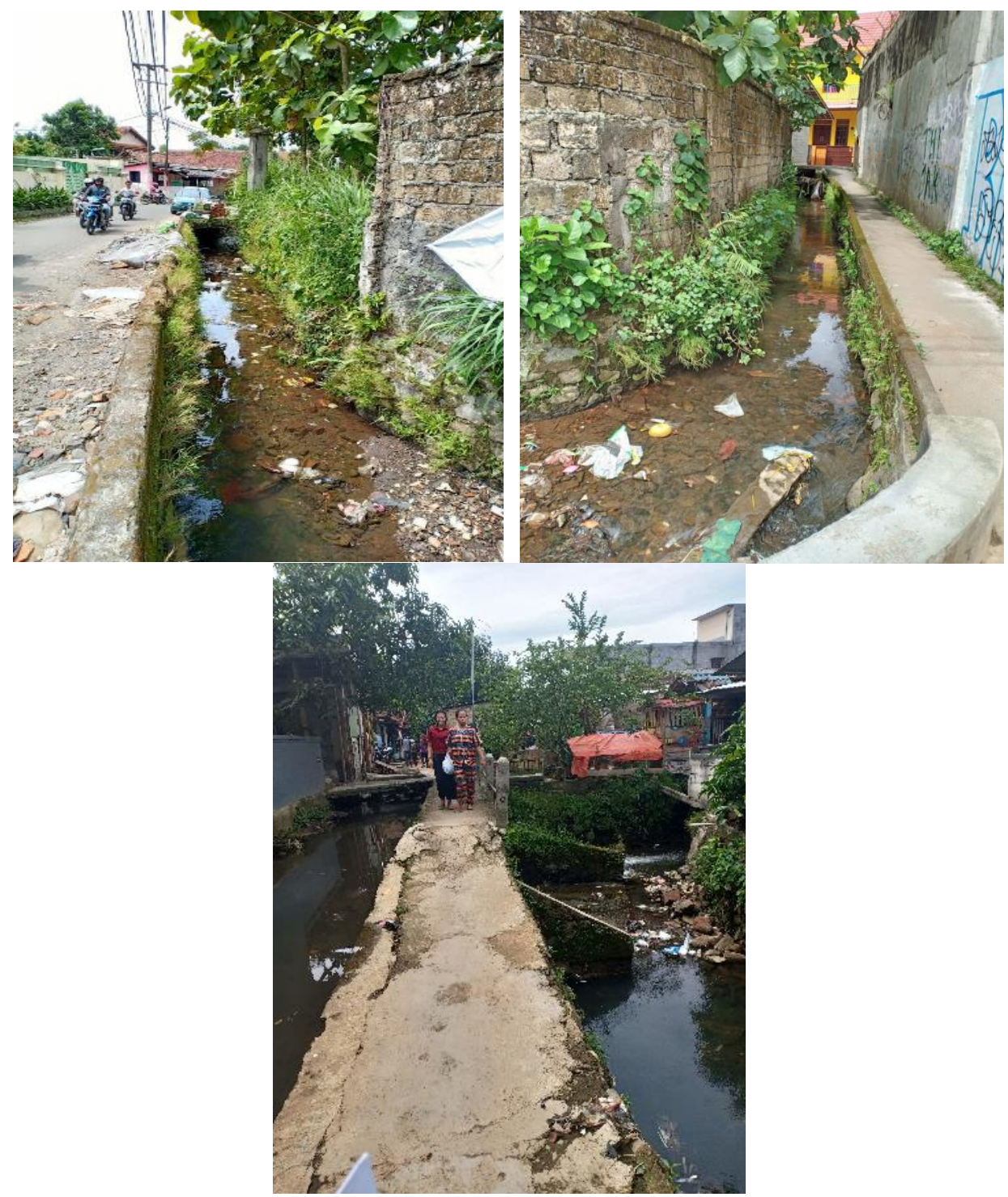

Gambar 3. Saluran Drainase di Kelurahan Cikaret

(Sumber : Hasil Pengamatan, 2018)

Skala prioritas 2 meliputi Kelurahan Kertamaya (RW 5 di RT 01 dan RT 02 Jalan Rancamaya Bojongkerta), dan Kelurahan Lawanggintung (RW 1, Jalan Lawanggintung). Meskipun berdasarkan skoring nilainya tidak terlalu besar, namun tetap masuk sebagai prioritas penanganan genangan atau banjir karena di Kelurahan Kertamaya belum terdapat saluran drainase di sisi kanan dan sisi kiri jalan. Kemudian di Kelurahan Lawanggintung lamanya genangan yang terjadi 4 jam, dan akan surut dalam kurun waktu 5 jam, selain itu lokasi ini cukup strategis karena berdekatan dengan tempat Paspamres (Pasukan Pengamanan Presiden) maka dibutuhkan penanganan perbaikan saluran drainase berdasarkan kondisi eksisting lamanya genangan. Lamanya genangan dapat menyebabkan terjadinya penyakit dari sebaran vektor penyakit.

Guna menghindari siklus hidup perkembangbiakan vektor penyakit (nyamuk) perlu dibuat drainase dengan keadaan lingkungan yang baik diantaranya dengan menghindari 
genangan air dipermukaan tanah dengan perbaikan sistem drainase, dan meninggikan permukaan tanah supaya tidak terjadi genangan air (Joetata, 1997).

Berdasarkan Peraturan Menteri Pekerjaan Umum dan Perumahan Rakyat No.12 Tahun 2014 pasal 6 ayat 2 perlu dilakukan pengembangan sistem drainase perkotaan menjadi sistem drainase perkotaan yang berkelanjutan dan berwawasan lingkungan, maka diperlukan perbaikan saluran drainase. Konsep drainase yang berwawasan lingkungan yaitu air hujan yang jatuh ke badan jalan harus secepatnya dialirkan ke saluran tepi jalan (menghindari tergenangnya air di permukaan jalan). Konsep ini mengupayakan supaya air sebelum diteruskan dan disalurkan ke saluran pembuangan atau badan air sungai, maka air di diusahakan meresap ke dalam tanah, guna meningkatkan kandungan air tanah untuk cadangan pada musim kemarau. (Sailendra, 2011).

Metode drainase ramah lingkungan yang dapat dipakai di Indonesia, diantaranya adalah metode kolam konservasi, metode sumur resapan bersifat sebagai bangunan penahan air (kolam) (Permen PU, 2014).

Selain metode untuk mengkonservasi air, dapat juga melakukan pemeliharaan saluran drainase seperti dilakukannya pengerukan sedimen saluran drainase tipe terbuka yang dilakukan satu atau dua kali dalam setahun, biasanya dilaksanakan di musim kemarau. (Permen PU, 2014)

Untuk tanggul yang rusak, dapat dilakukan pemeliharaan dan rehabilitasi terhadap tanggul. Rehabilitasi tanggul dapat dilakukan dengan pemadatan tanggul yang rusak dengan lapisan-lapisan tanah per lapisan harus benar-benar padat dipadatkan secara berulang sedangkan pemeliharaan tanggul dengan pemotongan rumput liar dan pemotongan pohon-pohon liar yang berpotensi untuk menganggu konstruksi tanggul.

\section{PENUTUP}

Dari 18 titik genangan, didapat 9 titik prioritas yang merupakan hasil penilaian skala prioritas genangan atau banjir berdasarkan Peraturan Menteri Pekerjaan Umum dan Perumahan Rakyat No.12 Tahun 2014. 9 titik tersebut tersebar pada 4 kelurahan, yakni Kelurahan Lawanggintung, Kertamaya, Cikaret dan Batutulis. Pada Kecamatan Bogor Selatan terdapat 6 titik skala prioritas 1, dan 3 titik skala prioritas 2. Upaya perbaikan dapat dilakukan dengan adanya rekomendasi perbaikan saluran drainase. Upaya perbaikan dengan rekomendasi perbaikan saluran drainase antara lain dengan adanya ecodrainage meliputi pembuatan sumur resapan, biopori dan kolam retensi, perbaikan tanggul, normalisasi saluran seperti adanya pembesaran dimensi, pembuatan saluran baru dan perawatan saluran secara berkala untuk membersihkan endapan sampah.

\section{UCAPAN TERIMA KASIH}

Terimakasih saya ucapkan kepada Universitas Tanjungpura, serta Bu Eka Wardhani S.T., M.T dan Bu Lina ST., M.T selaku pembimbing yang telah membantu pengerjaan penelitian ini dan teman-teman teknik lingkungan 2015.

\section{DAFTAR PUSTAKA}

Badan Perencanaan Pembangunan Daerah Kota Bogor.2018. Masterplan Drainase Kota Bogor Tahun 2018. Bogor. BAPPEDA Kota Bogor.

Joetata, Hardihardaja. 1997. Drainase Perkotaan. Jakarta: Gunadarma 
Jurnal Teknologi Lingkungan Lahan Basah, Vol. 07, No. 2, 2019: 081 - 091

Peraturan Menteri Pekerjaan Umum Nomor 12 Tahun 2014 tentang Penyelenggaraan Sistem Drainase Perkotaan.

Sailendra, Agus Bari. 2011. Perencanaan Drainase dan Bahu Jalan Yang Berwawasan Lingkungan. Bandung: Puslitbang Jalan dan Jembatan

Suripin. 2004. Sistem Drainase Perkotaan yang Berkelanjutan. Yogyakarta. ANDI Offset. 